\title{
Ovarian Cancer and Primary Peritoneal Carcinoma pT2a TNM Finding v7
}

National Cancer Institute

\section{Source}

National Cancer Institute. Ovarian Cancer and Primary Peritoneal Carcinoma pT 2a TNM

Finding V7. NCI Thesaurus. Code C89647.

Ovarian cancer or primary peritoneal carcinoma with extension and/or implants on uterus and/or tube(s). No malignant cells in ascites or peritoneal washings. (from AJCC 7th Ed.) 